\title{
Opinião
}

\section{O AMOR NAS RELAÇÕES SOCIAIS}

\author{
Julyanne de Oliveira Paes Barreto (1)
}

A emoção fundamental que torna possível todas as outras é o amor. Entende-se aqui o amor como algo constitutivo da vida humana. O amor é o fundamental do social, mas nem toda a convivência é social. O amor é a emoção que constitui o domínio de condutas em que se dá a operacionalidade do outro na convivência, e é esse modo de convivência que conotamos quando falamos do social.

O amor é uma construção social. E como tal, em cada época, ele acontece de uma maneira. Ao longo do tempo, tomou características diferentes. O amor romântico é apenas uma das dimensões do amor social. Em geral, trás consigo um conjunto de expectativas e idéias.

As relações sociais se fundam na aceitação do outro, na convivência, numa conduta de respeito, numa aceitação mútua, num espaço aberto às coordenações de ações, na linguagem. Entendamos aqui a linguagem como domínio de coordenações consensuais de conduta, que exige uma convivência constituída na operacionalidade da aceitação mútua. O que sabemos sobre o modo de vida de nossos antepassados nos revela que isso tem que ter ocorrido na história evolutiva, conservando-se até hoje em nós.

Ainda somos animais colheitadores, ainda somos animais compartilhadores, vivemos ainda na coordenação consesual de ações, ainda vivemos em pequenos grupos, vivemos a sensualidade no encontro personalizado com o outro. Ainda somos animais dependentes do amor, sobretudo no presente momento da história evolutiva a que pertencemos, história essa que tem sua origem na linguagem, fazendo parte do modo de vida.

O amor é a emoção central na história evolutiva humana desde o início, e toda ela se dá como uma história em que a conservação de um modo de vida no qual o amor, a aceitação do outro como um legítimo outro na convivência, é uma condição necessária para o desenvolvimento físico, comportamental, psíquico, social e espiritual normal da criança, 
assim como para a conservação da saúde física, comportamental, psíquica, social e espiritual do adulto. O homem origina do amor e é dependente dele, $99 \%$ da enfermidade humana tem a ver com a negação do amor.

A emoção que funda o social como a emoção que constitui o domínio de ações no qual o outro é aceito como legítimo outro na convivência, é o amor.

Relações que não estão fundadas no amor, não são relações sociais. Nem todas as relações humanas ou comunidades humanas são sociais, porque nem todas se fundam da aceitação mútua.

\section{Sobre a autora:}

(1) Julyanne de Oliveira Paes Barreto é Graduada pela Faculdade Ítalo-Brasileira - SP, Coordenadora do Curso de Extensão de Formação de Comissãrios de Vôo pela FACISA - Faculdade de Ciências Aplicadas de Campina Grande - PB.

E-mail: July_paes2@hotmail.com 